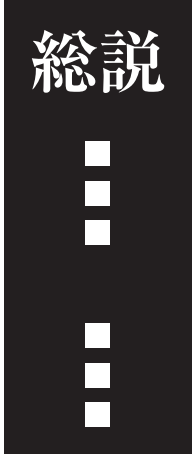

\title{
細胞外 $\mathrm{pH}$ 環境を感知する プロトン感知性 GPCR の機能と作用機構
}

\author{
戸村 秀明, 茂木 千尋, 佐藤 幸市, 岡島 史和
}

要 約 : OGR1（Ovarian cancer G-protein-coupled receptor 1), GPR4, TDAG8 (T-cell death-associated gene 8), G2A (G2 accumulation) は, お互いのアミノ 酸の相同性が 40-50\%の Gタンパク質共役型受容体 （GPCR）である。これらの受容体は最初, 脂質性メデ イエーターに対する受容体として報告されたが，2003 年の Ludwig らによる報告以降, これらの受容体が細 胞外プロトンを感知するプロトン感知性 GPCRである ことが，明らかとなった，OGR1，GPR4，G2Aが脂質 メディエーターである sphingosylphospholylcholine (SPC) や lysophosphosphatidylcholine（LPC）に対す る受容体であるとの説は, 受容体への結合実験の再現 性の問題から, 現在は疑問視されている. 細胞外 $\mathrm{pH}$ の低下に伴いプロトン感知性 GPCR は, 受容体中のヒ スチジンがプロトネーションされる結果, 立体構造が 活性型に移行し, 種々の三量体 G タンパク質を介して, 多様な細胞内情報伝達系を活性化させると考えられて いる. G2A に関しては生理的な $\mathrm{pH}$ 条件下で恒常的な 活性化が観察されるので, 別の活性化機構が提唱され ている. 生体内の $\mathrm{pH}$ は 7.4 付近に厳密に調節されて いることから, 細胞外 $\mathrm{pH}$ の低下は炎症部位やがんな ど局所的に起こっていることが予想される，実際，炎 症やがんなどで, プロトン感知性 GPCR を介した作用 が, 我々の報告を含め, 細胞レベル, 個体レベルで報 告されている。これまでの研究結果から, 発現するプ ロトン感知性 GPCR の種類の違いにより, 炎症部位で 異なる応答が惹起される可能性が浮上してきた，さら に最近, 各受容体の欠損マウスの報告が出そろい, プ ロトン感知性 GPCRの研究は新たな段階に入ってきた. プロトン感知性 GPCR の研究は, 炎症やがんに対する 新たな視点からの創薬へのきっかけにつながる可能性
を秘めている。

\section{はじめに}

OGR1 (Ovarian cancer G-protein-coupled receptor 1), GPR4, TDAG8 (T-cell death-associated gene 8), G2A（G2 accumulation）は，お互いのアミノ酸の相同 性が 40-50\%の G タンパク質共役型受容体（GPCR） である。これらの GPCRは最初, sphingosylphosphorylcholine (SPC), lysophosphosphatidylcholine (LPC), psychosine な゙の脂質性メディエーターに対 する受容体として報告された(1).しかしながら， 2003 年に Ludwig らにより OGR1，GPR4 が(2)，そし て 2004 年から 2005 年にかけて我々を含む複数のグル ープにより $\operatorname{TDAG8}(3,4), \mathrm{G} 2 \mathrm{~A}(5)$ が, 細胞外プロト ンを感知するプロトン感知性 GPCRであることを報告 した。

プロトン感知性 GPCR の作用に関しては, 細胞を用 いた in vitroでの研究に加え, 最近では各受容体を欠 損するマウスを使用した in vivo での研究がなされる ようになってきた。

本総説では, プロトン感知性 GPCR の活性化機構に 加え, 炎症, がんに対するプロトン感知性 GPCR の役 割に関する研究の現況を紹介したい。

\section{1. プロトン感知性 GPCR の活性化機構}

プロトン感知性 GPCRは, 細胞外プロトンにより活 性化され，他の GPCR と同様に三量体 G タンパク質を 介して，細胞内情報伝達系を活性化する．Ludwig ら の最初の報告(2) では, OGR1 は phospholipase C (PLC) $/ \mathrm{Ca}^{2+}$ 系を活性化すること，GPR4 は cAMP 産 生系を活性化することが示されている．TDAG8に関

キーワード : OGR1, GPR4, TDAG8, G2A，プロトン感知性 GPCR

群馬大学 生体調節研究所シグナル伝達分野（テ371-8512 前橋市昭和町 3-39-15)

E-mail: tomurah@showa.gunma-u.ac.jp 原稿受領日：2010 年 2 月 22 日, 依頼原稿

Title: Proton-sensing G-protein-coupled receptors and their physiological roles

Author: Hideaki Tomura, Chihiro Mogi, Koichi Sato, Fumikazu Okajima 
しては，我々が cAMP 産生系を活性化すること(3), Ishii らは cAMP 系に加え RhoA を活性化すること (4) を示した，G2A に関しては Murakami らにより，Rho 系を介した zif268 プロモーターの活性化と $\mathrm{PLC} / \mathrm{Ca}^{2+}$ 系の活性化を引き起こすことが示された(5).ささらに 我々は，GPR4 が異なる種類の三量体 G タンパク質を 介して, cAMP 産生系以外に, $\mathrm{G}_{13} / \mathrm{Rho}$ 系, $\mathrm{G}_{\mathrm{q} / 11} / \mathrm{PLC}$ 系など，多様な情報伝達系を活性化することを示した (6). 以上の知見は受容体を過剩発現して得られた結 果であるが，プロトン感知性 GPCR をネイティブに発 現する細胞においても, 細胞外 $\mathrm{pH}$ の低下がプロトン 感知性 GPCR を介して, 種々の細胞内情報伝達系を活 性化することは, 我々を含めて報告されている $(7-$ 11).

プロトンの受容体への結合は，直接測定することが できない，そこで我々は，プロトンが直接に受容体を 活性化しうることを, TDAG8 過剩発現細胞の細胞膜 標品を用いて報告した(3)。プロトン感知性 GPCR は, 受容体中のヒスチジンのプロトネーションにより活性 化するというモデルが，提唱されている(2)。実際，ヒ スチジンをフェニルアラニンに変異させた受容体では, 活性化が減弱する $(2,3,5)$. なお G2A に関しては，プ ロトンによる受容体の活性化に疑問を呈する報告もな されている(9)，G2A のアミノ酸配列を OGR1，GPR4， TDAG8 のそれと比較すると, プロトンを感知すると スチジンの位置に，塩基性アミノ酸であるリジン残基 やアルギニン残基が存在している。このため, 生理的 $\mathrm{pH}$ では $\mathrm{G} 2 \mathrm{~A}$ はすでに活性化しているとの仮説が提唱 されている (12)。実際， G2A は生理的な $\mathrm{pH}$ 条件下で 活性化している $(5,6)$. 次に述べるように, G2A は別 の機構によりその活性が調節されている可能性が高い

SPC や LPC の OGR1，GPR4，G2Aへの特異的な結 合が再現できないことや，我々を含めこれら脂質性メ ディエーターのアゴニスト作用が観察できない場合も 多いため, プロトン感知性 GPCR が SPC や LPC に対 する受容体であるとの説は，現在，疑問視されている． プロトン感知性 GPCRを最初に報告したノバルテイス のグループでは, OGR1, GPR4 に対してプロトン以外 のリガンドは見いだせないことを報告している (13). 実際，SPCや LPCが受容体を活性化するデー夕は我々 も得ていない $(7,8)$. しかしながら依然として，これ ら脂質性メディエーターがプロトン感知性 GPCRを発 現する細胞に対して, 各種細胞応答を引き起こすとの 報告は, 続いている (14-27)。 また 9-HODEが G2Aの リガンドあるとの報告 $(28)$ もなされており，プロトン 感知性 GPCRの活性調節に脂質性メディエーターが何
らかの作用を及ぼしていることは確かと思われる。脂 質性メデイエーターは，単独で受容体を活性化する (1, 29），プロトンによる受容体の活性化を阻害する (3, 5, 30), 受容体の細胞内から細胞膜への発現に関与する (25,31) など，種々の報告が混在している。 しかしな がら，上述したようにLPC，SPCの OGR1，GPR4, G2Aへの特異的な結合を報告した論文は，再現性の問 題から撤回されており, これらの結果の解釈には注意 が必要である。また活性化の阻害に関しては，LPCを 除き脂質性メディエーターの濃度が生理的な濃度とか け離れて抢り，実際に生体内で作用しているものとは 考えにくい，その点, G2Aの細胞膜への発現にLPCが 関与するとの報告 $(25,31)$ は，上述のように恒常的に 活性化している G2A に対する LPCの新たな活性調節 機構として, 注目される.

\section{2. プロトン感知性 GPCR の生理，病態生理的 な作用}

生体内の $\mathrm{pH}$ は 7.4 付近に厳密に調節されている. しかしながら, 細胞外 $\mathrm{pH}$ の低下は炎症部位やがんな どで，局所的に引き起こされている，本総説では，炎 症，がんを中心に，プロトン感知性 GPCR をする作 用を紹介したい。

\section{1）炎症応答とプロトン感知性 GPCR}

生体は各種ストレスにさらされると, ストレス周辺 の細胞やその部位に遊走，浸潤してきた免疫細胞から， プロスタグランジン類や炎症性サイトカインなどの炎 症関連物質が産生され，炎症応答が惹起される。また 炎症部位は，感染した細菌からの脂肪酸の産生や炎症 周辺の細胞での解糖系の立進による乳酸産生の増加な どにより， pH が低下する．細胞外液の $\mathrm{pH}$ の低下が， 炎症部位の細胞の機能に多彩な影響を及ぼすことはよ く知られているが，その分子機構はほとんど明らかと なっていない.

\section{(1) OGR1}

OGR1 は, 多くの組織でその発現が観察される.動 脈硬化は血管に生じる炎症の一種であり，血管平滑筋 細胞の脱分化に伴う増殖・遊走が, 動脈硬化の維持, 進展に大きな役割を果たす。我々はヒト大動脈血管平 滑筋細胞 (AoSMC) を用い, 細胞外 $\mathrm{pH}$ の低下は OGR1 を介して，PLC/extracellular signal-regulated kinase (ERK)/cyclooxygenase（COX）を活性化し, $\mathrm{PGI}_{2}$ の 産生を引き起し, $\mathrm{PGI}_{2}$ 受容体を介して AoSMCの cAMP 産生を増加させることを報告した (7)， $\mathrm{PGI}_{2}$ は 抗動脈硬化作用を示すこと, cAMP は血管平滑筋細胞 の増殖や遊走を抑制することから，OGR1は動脈硬化 
を調節する可能性がある，さらに我々は，細胞外 $\mathrm{pH}$ の低下が OGR $1 / \mathrm{G}_{\mathrm{q} / 11} / \mathrm{COX}-2$ を介して, ヒト骨芽細胞 （NHost）に打いて $\mathrm{PGE}_{2}$ の産生を引き起こすことも報 告した(8)。COX-2 は各種炎症物質によりその発現が 誘導される，プロスタグランジン産生酵素である。 我々は細胞外 $\mathrm{pH}$ の低下が COX-2 の発現を誘導するこ と, そしてこの発現の誘導も, OGR1 を介して引き起 こされていることを明らかにした（8）（Liu他, 未発表 データ)。これらの結果は, OGR1 が炎症時の細胞外 $\mathrm{pH}$ の低下に伴う COX-2 の発現やプロスタグランジン 類の産生に関与することを示している.

炎症性サイトカインの産生にも OGR1 は関与する。 喘息では，気管支内の $\mathrm{pH}$ が低下している。我々は七 卜気管支平滑筋細胞を用い, 細胞外 $\mathrm{pH}$ の低下が OGR1 を任-6の発現や産生を誘導することを 見出している (Ichimonji 他, 未発表データ).

このように OGR1 は細胞外 $\mathrm{pH}$ に伴うプロスタグラ ンジン類や炎症性サイトカインなどの炎症関連物質の 産生を促進し, 炎症応答を調節する可能性がある。

実際に OGR1 が炎症応答に関与していることは, OGR1 欠損マウスで示された. チオグリコレート処理 による炎症モデルでは, 欠損マウスでは腹垫内マクロ ファージの数が少ないこと, また欠損マウスのマクロ ファージは LPS による ERK の活性化や NO 産生が減 弱していることが示されている(32).

他, 細胞外 $\mathrm{pH}$ の低下が OGR1 を介して, 破骨細胞 の生存, 分化, 活性化に関与することが報告されてい る(33-35). 上述のように OGR1 は骨芽細胞の細胞応 答も引き起こすことから, OGR1 欠損マウスでは骨組 織に何らかの異常があることが予想されたが, 正常マ ウスと大きな差は観察されていない (32). アシドーシ スなど生体にストレスを負荷することにより，正常と 欠損マウス間で差が検出されるのかもしれない.

\section{(2) TDAG8}

TDAG8 は, 血球系細胞に非常に強い発現が観察さ れることから，これらの細胞での作用解析が進んでい る. 感染による炎症時には, 好中球から活性酸素が産 生され, 感染を防御する。 ヒト好中球では FMLPによ り産生される活性酸素量が細胞外 $\mathrm{pH}$ の低下に伴い抑 制されるが，この抑制は過剩な炎症応答に対する一種 のネガティブフィードバック作用と考えられる. 我々 はTDAG8の発現が, ヒト白血病細胞株である HL60 が好中球様に分化する過程で増加すること, 細胞外 $\mathrm{pH}$ の低下に伴い TDAG8 は cAMP 産生系を活性化す ること, 活性酸素の産生の抑制には cAMP/protein kinase A (PKA) 経路が関与していることを見出し, こ
の抑制作用に TDAG8 が関与している可能性を示唆し た(36)。ささら我々は実際に生体内で TDAG8 が炎症 応答を抑制する可能性を, TDAG8 欠損マウス由来の 腹腔内マクロファージを用いて示した. マクロファージで は, 細胞外 $\mathrm{pH}$ の低下に伴い LPS 刺激に伴う TNF $\alpha$ や IL-6 の産生が抑制される. TDAG8 久損マウス由来の 腹腔内マクロファージでは，この抑制が部分的に解除 されていたそそしてその部分的な抑制にはTDAG8を 介した $\mathrm{G}_{\mathrm{s}} / \mathrm{cAMP} / \mathrm{PKA}$ 経路が関与していることを示し た(10)。このように TDAG8 は炎症性サイトカインや 活性酸素の産生を抑制することで, 炎症応答を調節し ている可能性がある。これは, OGR1 がプロスタグラ ンジン類や炎症性サイトカインの産生を促進するのと は対照的である。プロトン感知性 GPCRの種類によっ て, 細胞外 $\mathrm{pH}$ の低下が炎症反応に対して異なる応答 を惹起する可能性がある（図 1).

TDAG8 は血球系細胞のアポトーシスにも関与する. 好中球の分化には G-CSF/STAT3 系の活性化が必要で ある. STAT3 $\alpha$ の過剩発現は, 好中球の細胞死を抑制 する. STAT3の発現により TDAG8 が誘導されること から, TDAG8 が cAMP系の活性化を介して好中球の 細胞死の抑制に関与する可能性が報告されている(37). 実際, TDAG8 が血球系細胞のアポトーシスの抑制に 関与することは, TDAG8 久損マウスを用いて報告さ れている. マウスの気管アレルギーモデルにおいて, 肺での好酸球数の増加が欠損マウスでは少ないこと, TDAG8 欠損マウス由来の好酸球では $\mathrm{pH}$ 低下で $\mathrm{cAMP}$ 産生が増加しないことが示されている。この結果は,

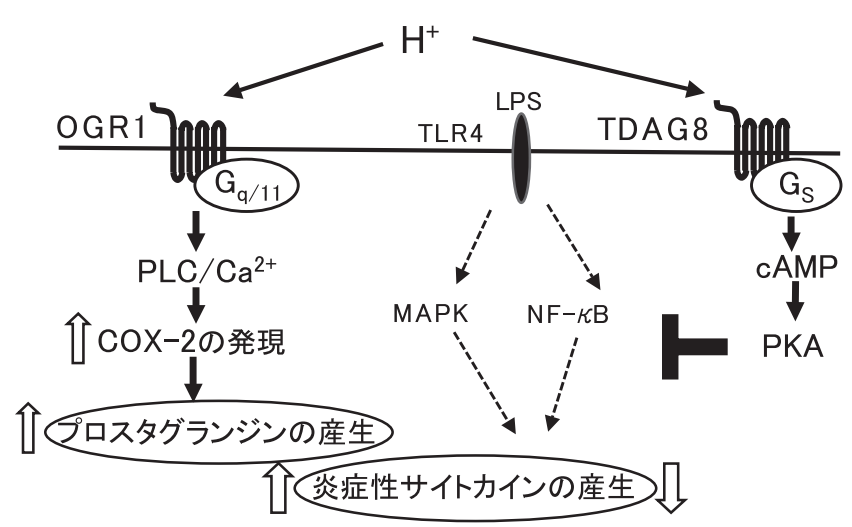

\footnotetext{
図 1 プロトン感知性 GPCR の違いによる炎症関連物質の産生促 進と抑制

炎症時の細胞外 pH の低下に伴い, OGR1 は COX-2 の発現誘導を引き 起こす (Tomura, et al. JBMR 2008 (文献 8), Liu, et al. 未発表デー タ). またプロスタグランジン類や (Tomura, et al. JBC 2005 (文献 7), Tomura, et al. JBMR 2008 (文献8)), 炎症性サイトカイン (Ichimonnji, et al. 未発表データ) などの炎症関連物質の産生を促進す る.一方, TDAG8 は CAMPの産生を介して, 炎症性サイトカインの産 生を抑制する (Mogi, et al. Jl 2009 (文献 10)).
} 
TDAG8 が cAMP 産生を介して好酸球のアポトーシス を抑制することで，アレルギー条件下での好酸球の増 加を促進することを示している(11).

一方, TDAG8 の欠損マウスの免疫組織の形態, 機 能は正常なものと同様であることから, TDAG8 の作 用は不明であることの報告もなされている $(38)$ ，上述 のように TDAG8 は，炎症時など生体がストレスにさ らされた時に，その作用を発揮するのかもしれない.

他, 炎症時の神経の痛覚症状などにプロトンが関与 することが知られている，プロトン感知性 GPCRが新 たな痛覚センサーである可能性があることから，神経 系においても TDAG8 に関する細胞レベルでの解析の 報告がなされている(39-41).

\section{(3) GPR4}

GPR4 は多くの組織でその発現が観察されるが, 血 管内皮細胞で強い発現が観察されることから, 現在ま でにこの受容体の血管系への作用を解析した報告が多 い.

ヒト胎盤血管内皮細胞（HUVEC）では，細胞外 $\mathrm{pH}$ の低下に伴い cAMP 産生が起こること, その産生は GPR4 を HUVEC に過剩発現させると促進されること， GPR4 はHUVECの遊走を $\mathrm{pH}$ 依存的に抑制することが Yang らにより報告されており (42), 細胞外 $\mathrm{pH}$ の低下 がGPR4/cAMPを介して細胞の遊走を抑制することが 予想された. 実際Y Yang らは, 正常マウスと欠損マウ スより大動脈を単離し, 細胞外 $\mathrm{pH}$ の低下に伴う細胞 の遊走と増殖活性の抑制の程度が, 久損マウスでは減 弱することを示した (42)。この結果は, GPR4 が炎症 時に内皮細胞の増殖や遊走を調節する可能性を示唆し ている，実際，ヒト頭毛細血管内皮細胞では，炎症性 サイトカインである TNF $\alpha$ でGPR4 の発現が上昇する (16)。また Yang らは， 欠損マウスの一部に微小血管 からの出血や血管の変形も観察しており, 正常の微小 血管の形成や維持にも GPR4 が関与することを示して いる (42).

他, GPR4 は, 血管内皮細胞における単球のトラン スマイグレーション(17)や, 血管のバリアー機能 (19) に関与することが報告されている. なおこれらの報告 では, プロトンよりはむしろ LPCがこれらの応答に関 与することが示されている。 しかしながら，上述した ようにLPCの GPR4への結合を報告した論文は再現性 の問題から撤回されており,この結果の解釈には注意 が必要である，G2Aで報告されているように, LPCが GPR4 の細胞膜への発現に関与している可能性もある. SPC が内皮細胞の管空形成, 増殖, 生存, 遊走に GPR4 を介して関与することが報告されている $(20)$ ．この報
告も LPC の場合と同様の理由により, 結果の解釈には 注意が必要である。

\section{(4) $\mathrm{G} 2 \mathrm{~A}$}

上述のように G2A は生理的 $\mathrm{pH}$ では恒常的に活性化 しており，またLPCにより活性調節をうけることから， 単純にプロトン感知性 GPCR とはいえないかもしれな い. しかしながらこの受容体に対するこれまでの知見 は，今後，OGR1，TDAG8，GPR4 が関与する作用の 解明の手がかりになる可能性がある.

G2A は TDAG8 と同様に, 血球系の細胞に非常に強 い発現が観察されることから，これらの細胞での作用 の解析が主に行われてきている，G2A は，LPCが引き 起こすマクロファージやT細胞の遊走に $(22,23)$, LPC による好中球やマクロファージの活性化に $(24-27)$, 単球細胞のどん食作用に(14) 関与することが, これま でに報告されている。これらの応答は炎症時に観察さ れる応答であり，G2A は炎症応答を調節している可能 性が高い。

G2A 欠損マウスに関しては, 高齢で自己免疫様の疾 患症状を呈することが報告されたが(43)，最近，使用 したマウスの遺伝的背景によっては自己免疫疾患様の 症状を呈さない例も報告されている(44)。また免疫細 胞の遊走や浸潤応答を介して, 動脈硬化の維持, 進展 にG2Aが関与することも報告されている $(45,46)$ 。さ らに最近, 肝臓に発現する G2A が HDL の産生を抑制 しているとの報告もなされている(47)。このように個 体レベルにおいても, 炎症応答に G2Aが関与すること を示す報告がなされている.

\section{2）がんとプロトン感知性 GPCR}

がんは解糖系が充進し, 不十分な血管形成により酸 素の供給が不足するので, その組織内の $\mathrm{pH}$ は低下し ている. pH の低下は細胞の増殖や遊走を始め, さま ざまな応答を変化させるので, プロトン感知性 GPCR が抗がん風の新たなターゲットとなる可能性があるこ とから, がんとプロトン感知性 GPCR との関係は, 興 味が持たれている。

OGR1 はヒト筋芽腫組織や細胞に発現し, 細胞外 $\mathrm{pH}$ の低下に伴い, 細胞内 $\mathrm{Ca}^{2+}$ の上昇, PLC 活性の上 昇, ERK の活性化を引き起こすことが報告されている (48)。またヒト前立腺がんでは, OGR1 の発現量に比 例して浸潤能が低下することが示されている(49)。実 際にメラノーマ細胞による腫瘍化は, OGR1 欠損マウ スで抑制されることが報告され (32)，がんの腫瘍化と OGR1 の関連が個体レベルで示唆されている. GPR4, TDAG8に関しては，細胞レベルで，またはヌードマ ウスへの接種実験による個体レベルで, これらの受容 
体がリガンド非依存性にがん化を引き起こすがん遺伝 子である可能性が報告されている(49)。ささらに実際の がん細胞において，これらの受容体が過剩発現してい ることも示されている(49). また, ヒト TDAG8 の遺 伝子が白血病と関連する遺伝子座付近にあることも報 告されている $(50)$. G2A に関しては, 発見当初, この 受容体はヒト白血病がん遺伝子である BCR-ABLチロ シンキナーゼの標的遺伝子として同定された経緯があ る.そこでこの白血病に対する G2A の作用が解析さ れている. マウスにおける BCR-ABLによる白血病誘 導モデルにおいて，この受容体が久損すると白血病の 進行が早まることが示された(51)。すなわち, この受 容体はがん抑制遺伝子である可能性が示唆されている.

以上のように, プロトン感知性 GPCR はがんの機能 に対して何らかの役割を担っている可能性が高い.

\section{おわりに}

プロトン感知性 GPCR の研究は, 各受容体の欠損マ ウスの報告が出そろったことで, 新たな段階に入って きた，今後, 細胞を用いた in vitroの研究と, 受容体欠 損マウスなどを用いた in vivo の研究の発展とともに, プロトン感知性 GPCR の生理, 病態生理学的な役割が 明らかになっていくものと思われる。 プロトン感知性 GPCRの研究の発展は, 炎症やがんに対して, 新たな 視点からの創薬へのきっかけにつながっていく可能性 を秘めている。

\section{文献}

1) Xu Y. Biochim Biophys Acta. 2002;1582:81-88.

2) Ludwig MG, et al. Nature. 2003;425:93-98.

3) Wang JQ, et al. J Biol Chem. 2004;279:45626-45633.

4) Ishii S, et al. J Biol Chem. 2005;280:9083-9087.

5) Murakami N, et al. J Biol Chem. 2004;279:42484-42491.
6) Tobo M, et al. Cell Signal. 2007;19:1745-1753.

7) Tomura H, et al. J Biol Chem. 2005;280:34458-34464.

8) Tomura H, et al. J Bone Miner Res. 2008;23:1129-1139.

9) Radu CG, et al. Proc Natl Acad Sci U S A. 2005;102:1632-1637.

10) Mogi C, et al. J Immunol. 2009;182:3243-3251.

11) Kottyan LC, et al. Blood. 2009;14:2774-2782.

12) Kostenis E. J Cell Biochem. 2004;92:923-936.

13) Seuwen K, et al. J Recept Signal Transduct Res. 2006;26:599-610.

14) Peter C, et al. J Biol Chem. 2008;283:5296-5305.

15) Jin Y, et al. Eur J Immunol. 2005;35:2699-2708.

16) Lum H, et al. Am J Physiol Heart Circ Physiol. 2003;285:H1786H1789.

17) Huang F, et al. Endothelium. 2007;14:25-34.

18) Zou Y, et al. Febs J. 2007;274:2573-2584.

19) Qiao J, et al. Am J Physiol Lung Cell Mol Physiol. 2006;291: L91-L101.

20) Kim KS, et al. Faseb J. 2005;19:819-821.

21) Singh LS, et al. J Natl Cancer Inst. 2007;99:1313-1327.

22) Yang LV, et al. Blood. 2005;105:1127-1134.

23) Radu CG, et al. Proc Natl Acad Sci U S A. 2004;101:245-250.

24) Yan JJ, et al. Nat Med. 2004;10:161-167.

25) Frasch SC, et al. J Immunol. 2007;178:6540-6548.

26) Frasch SC, et al. J Biol Chem. 2008;283:33736-33749.

27) Chen G, et al. J Lipid Res. 2005;46:623-627.

28) Obinata H, et al. J Biol Chem. 2005;280:40676-40683.

29) Im DS, et al. J Cell Biol. 2001;153:429-434.

30) Mogi C, et al. J Pharmacol Sci. 2005;99:160-167.

31) Wang L, et al. Mol Biol Cell. 2005;16:2234-2247.

32) Li H, et al. PLoS One. 2009;4:e5705.

33) Yang M, et al. J Biol Chem. 2006;281:23598-23605.

34) Iwai K, et al. J Bone Miner Res. 2007;22:1612-1620.

35) Pereverzev A, et al. Bone. 2008;42:150-161.

36) Murata N, et al. Cell Immunol. 2009;259:21-26.

37) Redell MS, et al. J Leukoc Biol. 2007;82:975-985.

38) Radu CG, et al. Mol Cell Biol. 2006;26:668-677.

39) Chen YJ, et al. Mol Pain. 2009;5:39.

40) McGuire J, et al. Biochem Biophys Res Commun. 2009;386:420425.

41) Huang CW, et al. Mol Cell Neurosci. 2007;36:195-210.

42) Yang LV, et al. Mol Cell Biol. 2007;27:1334-1347.

43) Le LQ, et al. Immunity. 2001;14:561-571.

44) Osmers I, et al. J Neuroimmunol. 2009;207:18-23.

45) Parks BW, et al. J Lipid Res. 2005;46:1405-1415.

46) Parks BW, et al. Arterioscler Thromb Vasc Biol. 2006;26:27032709.

47) Parks BW, et al. Arterioscler Thromb Vasc Biol. 2009;29:539-547.

48) Huang WC, et al. Curr Biol. 2008;18:781-785.

49) Sin WC, et al. Oncogene. 2004;23:6299-6303.

50) Kyaw H, et al. DNA Cell Biol. 1998;17:493-500.

51) Le LQ, et al. Cancer Cell. 2002;1:381-391. 